\title{
変形性膝関節症に対する脛骨粗面下骨切り術の治療経験
}

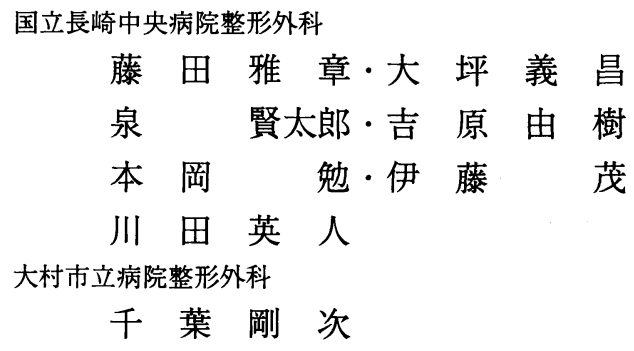

\section{Clinical Results of Proximal Low Tibial Osteotomy in Osteoarthritis of the Knee - Technique and Short Term Results-}

by

Masaaki Fujita, Yoshimasa Ohtsubo, Kentaro Izumi, Yoshiki Yoshihara, Tsutomu Motooka, Shigeru Itoh and Hideto Kawada

Department of Orthopaedic Surgery, Nagasaki Chuo National Hospital, Nagasaki, Japan

Takeji Chiba

Department of Orthopaedic Surgery, Ohmura Municipal Hospital, Nagasaki, Japan

High tibial osteotomies, both the wedge or dome type, are common in the treatment of osteoarthritis of the knee joint. However there is still some controversy remaining over whether the proximal fragment is too small to achieve a stable union using this technique.

We performed proximal low tibial osteotomy (PLTO) to resolve the above. This technique offers the following advantages:

(1) By using an equilateral triangular wedge osteotomy, the lateral cortical line is also adapted, and therefore a stable shape is maintained.

(2) Using the May plate, rigid fixation is obtained.

(3) Early rehabilitation is able to be carried out.

We report on nine cases (11 knees), 2 male and 7 female, whose ages ranged from 52 to 72 years (mean 63.5) who were operated on using the PLTO technique from April 1990 to October 1992. The follow-up interval was from 6 to 32 months (mean 63.5). The JOA score was used for the clinical evaluation, and for the radiological evaluation, mechanical axis (MA), femorotibial angle (FTA) and condylar plateau angle (CPA) were measured.

Good clinical and radiological results were obtained. On average the JOA score improved from 60 to 85 points, MA improved from $108.6 \%$ to $45 \%$, FTA from $185^{\circ}$ to $169^{\circ}$ and CPA from $6.3^{\circ}$ to $2.3^{\circ}$.

We concluded that proximal low tibial osteotomy (PLTO) was a useful technique especially for treating the moderate osteoarthritic knee joint in which the mechanical axis passes within the medial joint surface. 
Key words : Knee joint (膝関節), osteoarthritis (変形性関節症), proximal low tibial osteotomy（脛骨粗面下骨切り術）

$$
\text { はじめに }
$$

変形性膝関節症に対する脛骨骨切り術は, 一般に脛 骨粗面の高位で, wedge もしくは dome 型に矯正す る方法が一般的である。しかし近位骨片が小さいため 安定した骨癒合が得られない事など問題点も指摘され

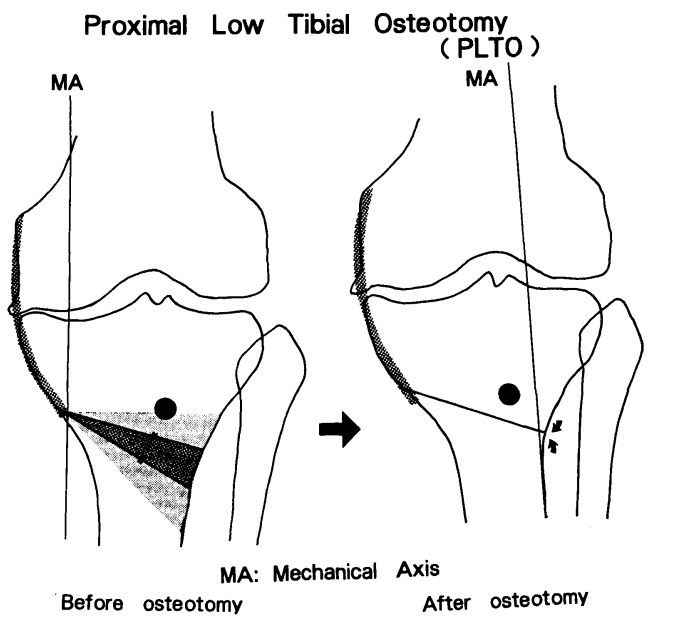

図 1 脛骨粗面下骨切り術 (PLTO). Wedge を二等 辺三角形に切除し骨皮質の適合を得, 一体化構 造を獲得する。
ている(1)2)，そこで我々は脛骨粗面下で二等辺三角形 の wedge 型骨切りを考按し, 骨皮質を適合させるこ とにより一体化構造を得, 強固な固定をして早期運動, 早期歩行のできる方法を施行している（図 1 ).

今回は本法の手術手技を紹介しあわせて短期成績を 報告し，その有用性につき他の手技と比較検討した。

\section{対象および方法}

対象は 1990 年 4 月より 1992 年 10 月までに手術施 行した 9 例（11 膝）で, 男性 2 例, 女性 7 例である.

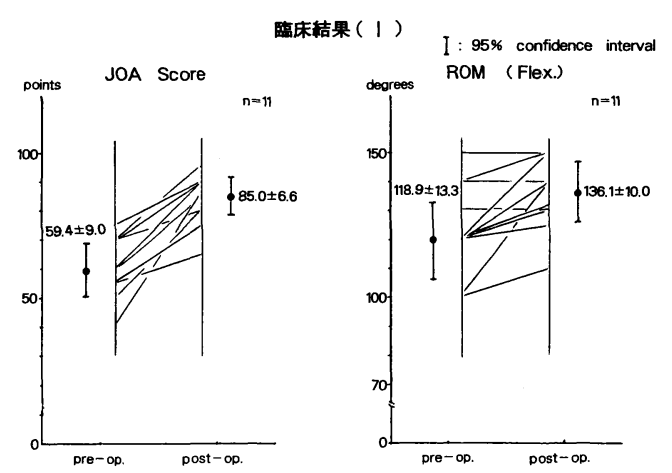

図 2 臨床結果（I ）。 JOA score と ROM (flex.) いずれも改善した。

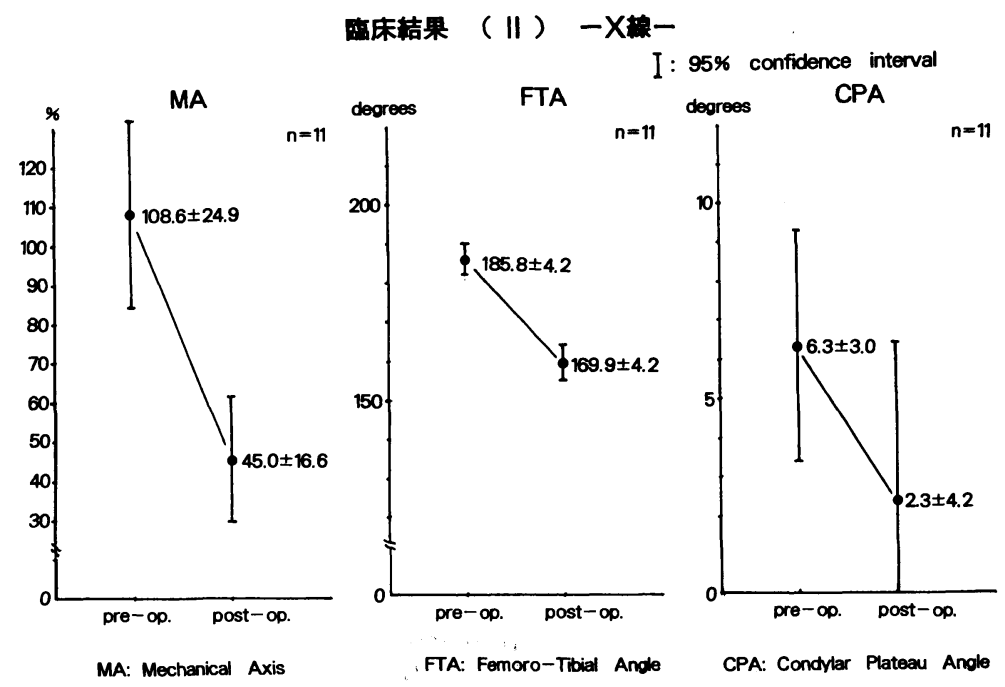

図 3 臨床結果 (II).X線：MA，FTA，CPA い ずれも正常範囲まで改善をみた。 
手術時年齢は 52 歳から 72 歳（平均 63.5 歳）で, 追 跡調査期間は 6 力月から 32 力月（平均 13.8 力月）で あった。臨床成績評価は JOA score を用い，X線評 価は, Mechanical axis (MA), Femoro-tibial angle (FTA), Condylar plateau angle (CPA) を計測した。

\section{手 術手技}

脛骨粗面の外側に関節面のレベルより約 $15 \mathrm{~cm}$ の斜 切開を加える，前脛骨筋を骨膜下に剥離し脛骨近位外 側面を展開する，骨切りの頂点を内側側副䩲帯付着部 より近位におき，Kirschner wire を垂直に立てる。 次に角度計を用いて水平線より $45^{\circ}$ の範囲で二等辺三 角形をデザインし，イメージ下に Kirschner wire を刺入する，次にbone saw と平ノミを用いて骨切 り術を施行する，骨片を除去し，ゆっくりと外反軸圧 をかけて内側の皮質をなるべく温存するようにし，外 側の骨皮質を合わせる，この時点で外反軸圧をかけ， イメージ下にアラインメントのチェックをし, May

Proximal Low Tibial Osteotomy (PLTO)

\section{A.K., 63yrs., Female}

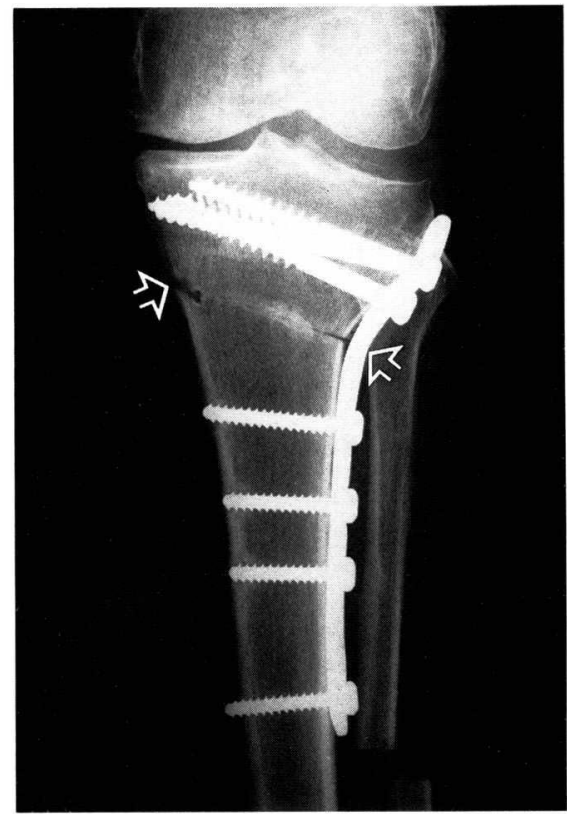

Post-op. 1w

図 4 症例 1.63yrs., Female. 術後 1 週のX 線正面 像. 骨皮質が内外側共適合しているのが分かる. plateにて固定する．吸引チューブを一本留置する． Robert-Jones dressing をし，簡易膝装具を装着す る.

\section{後療法}

翌日より CPM を用いての ROM 訓練を開始し， 荷重開始時期は $4 \sim 5$ 週とし, 全荷重は 8 週以降を目 安としている.

$$
\text { 結果 }
$$

図 2 に臨床成績を示す.JOA score では, 平均 60 点から 85 点と改善し, ROM (屈曲) 平均 $118.9^{\circ}$ か ら $136.1^{\circ}$ と改善の傾向がみられた。X線評価で は, MA が平均 $108.6 \%$ から $45 \%$, FTA は $185^{\circ}$ から $169^{\circ}$, CPA は $6.3^{\circ}$ から $2.3^{\circ}$ と正常值まで改善してい た（図 3 ）。また骨癒合までの期間は， 3 カ月から 6 力月 (平均 4.3 力月) とやや長期を要したが, 全例に 骨癒合が得られた。合併症は 1 例に腓骨神経不全麻痺 が認められた。

Proximal Low Tibial Osteotomy (PLTO)

A.K., 63yrs., Female

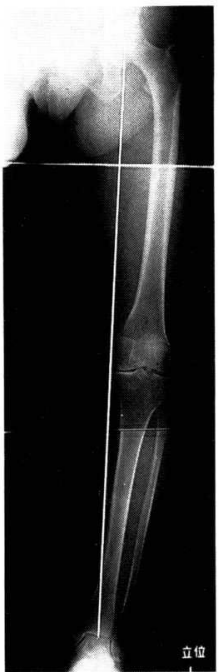

Pre-op.

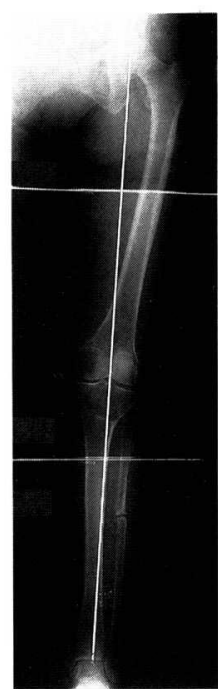

Post-op. 1Y
図 5 症例 1.63yrs., Female. 術後と術後 1 年の mechanical axis (MA) 97.0\%から $37.1 \%$ と改 善している。 
表 1 各手術術式の長所 ·短所

\begin{tabular}{l|c|c|c}
\hline \hline & \multicolumn{2}{|c|}{ 楔 状 型 } & ドーム型 \\
\hline \multicolumn{1}{c|}{ 脛 骨 粗 面 } & 高 位 & 低 位 & 高 位 \\
\hline (1)手術手技 & 難 & 易 & 易 \\
\hline (2)矯正角度 & 不 正 確 & 正 確 & 正 確 \\
\hline (3)術後調節 & 不 可 能 & 可能(術中) & 易 \\
\hline (4)後療法 & かなり難 & 易 & 易 \\
\hline (5)ギプス固定 & 要 & 不 要 & 不 要 \\
\hline (6)早期歩行 & 難 & 易 & 易 \\
\hline (7)可動域の維持 & や 難 & 易 & 易 \\
\hline (8)感染 & 少 & 少 & やや多い \\
\hline (9膝蓋大腿関節矯正 & 難 & 難 & 易 \\
\hline (1)骨療合期間 & 短 & やや長い & 短 \\
\hline
\end{tabular}

症

例

63 歳, 女性, 左変形性膝関節症, JOA score 70 点.

X線上, MA $97 \%$, FTA $185^{\circ}$, CPA $5^{\circ}$ であっ た. 術後 1 週のX線では, 内外側の皮質がほほ一致し, 一体化構造をなしていることがわかる（図 4 ）. 術後 1 年の抜釘後の下肢片脚立位X線では, MA $37.1 \%$, FTA $168^{\circ}$, CPA $3^{\circ}$ と十分な矯正が維持されていた (図 5 ). JOA scoreも 95 点と良好で, ADLも支障 なく, 正座も可能であり患者の満足度も高かった.

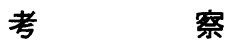

変形性膝関節症に対する脛骨粗面下骨切り術につい てはWagner の報告がある ${ }^{1)}$ ，脛骨粗面下で骨切り をする理由として (1) high dome や chevron osteotomies は安定した骨接合をするには近位骨片が 小さすぎること, (2) 脛骨粗面下は axial deformity の生じる pivot point であること, ( 3 ) medial cortex を温存するため distraction を防げることなどを あげている，矯正角度については, wedge base $4 \mathrm{~mm}$ が $10^{\circ}$ の矯正に相当するとしているが詳細については 伸べていない. Williams ${ }^{2)}$ は $45^{\circ}$ 斜位での骨切りを デザインし矯正角度の計算式を提示している．脛骨粗 面下骨切りの利点として, （1）血管損傷の危険が少 ないこと（2・）まだ海綿骨を含んでいること（3） 接触面積が大きいことなどをあげている．しかし 2 本 の screw で固定しており，6 週の長下肢ギプス固定
をしている.

本法は上記の利点に加え, 骨皮質がほほ適合するこ とで一体化構造を獲得し, さらにプレートによる強固 な固定をするため, 早期運動, 早期荷重が可能である.

そこで, 高位の wegde, dome 型骨切り術と本法 について, 手術手技, 矯正角度, 術後調節, 後療法, ギプス固定, 早期歩行, 可動域, 感染, 膝蓋大腿関節 の矯正, 骨癒合期間の 10 項目について比較検討した (表 1 ).

手術手技, および矯正角度については, 高位の wedge 型は難しく正確さにも難があるが本法および dome 型は比較的容易である. 術後調節 dome 型以 外は不可能であるが, 本法では術中イメージ下に調節 している. 後療法は dome 型と同様固定性が良好な ため, ギプス固定も不要で翌日より ROM 訓練が可 能である. 早期歩行についても, dome 型と同様 4 5 週で部分荷重歩行が可能である. したがって, 可動 域についても改善傾向がみられる. 感染例は本法では まだ経験しておらす, dome 型の創外固定例に比べる と危険性は少ない. 膝蓋大腿関節の治療は本法では不 可能であるが, 合併例に外側支帯解離術, 内側支帯縫 縮術を併用して良好な結果をえている，骨癒合期間に ついては他の方法と比べ, 平均 4.3力月とや長い傾向 がみられたが, 全例に骨瘉合が得られている（表 1 ）。 以上のことより，本法は他の手技と比べても遜色な く有用な方法と思われる.

また骨切り部の適合性を立体的に確認するため骨標 本にて $10^{\circ}$ の骨切りをしてみると, 断面積の差は 0.4 $\mathrm{cm}^{2}$ とほほ一体化構造が得られているのがわかる. 更 に $20^{\circ}$ の骨切りを加え, 骨切り面の形態と断面積をみ ると，形態も異なり，断面積の差も $1.2 \mathrm{~cm}^{2}$ と大きく なり, 骨切り部での適合性に限界があると思われた。

したがって, Mechanical axis (MA) が内側関 節面内にある中等度 $\mathrm{OA}$ を本手技の適応と考えてい る.

\section{ま と め}

(1)変形性膝関節症に対する脛骨粗面下骨切り術の手 術手技とその短期成績を報告しその有用性について他 の手技と比較検討した。

(2)臨床成績は, JOA score で平均 60 点から 85 点, $\mathrm{X}$ 線評価で MA は平均 $108.6 \%$ から $45 \%$, FTA は 
$185^{\circ}$ から $169^{\circ}, \mathrm{CPA}$ では $6.3^{\circ}$ から $2.3^{\circ}$ と改善され ていた。

(3)本症例は, 強固な固定ができ, 早期運動, 早期歩 行が可能であり中等度 OA には有用な方法と思われ る.

\section{参 考 文 献}

1) Wagner, H. et al.: Indikation, Technik und Eegebnisse der supra- und infracondy- lären Osteotomie bei der Kniegelenkarthrose. Orthopäde, $14:$ 172-192, 1985.

2) Williams, A.T.: Tibial realignment by oblique wedge osteotomy. International Orthopaedics (SICOT), 10 : 171-176, 1986. 